\title{
PENGEMBANGAN E-MODUL BERBASIS PROJECT BASED LEARNING PADA MATA PELAJARAN PEMROGRAMAN WEB KELAS X DI SMK NEGERI 3 SINGARAJA
}

\author{
I Kadek Adi Winaya1), I Gede Mahendra Darmawiguna2), \\ I Gede Partha Sindu ${ }^{3)}$ \\ ${ }^{1}$ Fakultas Teknik dan Kejuruan, Universitas Pendidikan Ganesha (penulis 1) \\ email: ikadekadiwinaya@gmail.com \\ ${ }^{2}$ Fakultas Teknik dan Kejuruan, Universitas Pendidikan Ganesha (penulis 2) \\ email: ,igd.mahendra.d@undiksha.ac.id \\ ${ }^{3}$ Fakultas Teknik dan Kejuruan, Universitas Pendidikan Ganesha (penulis 3) \\ email: partha.sindu@undiksha.ac.id
}

\begin{abstract}
Abstrak
Penelitian ini bertujuan (1) Untuk merancang dan mengimplementasikan Pengembangan E-modul Berbasis Project Based Learningpada Mata Pelajaran Pemrograman Web Kelas $X$ di SMK Negeri 3 Singaraja. (2)Untuk mengetahui respon siswa dan guru terhadap Pengembangan E-modul Berbasis Project Based Learningpada Mata Pelajaran Pemrograman Web Kelas X di SMK Negeri 3 Singaraja.

Metode penelitian yang digunakan dalam penelitian ini adalah penelitian dan pengembangan. dengan model pengembangan ADDIE. Subjek penelitian ini yaitu siswa kelas X Teknik Komputer dan Jaringan dan guru mata pelajaran Pemrograman Web di SMK Negeri 3 Singaraja tahun ajaran 2016/2017. Untuk mengetahui respon siswa dan guru terhadap e-modul diperoleh dengan menggunakan metode angket.

Hasil penelitian menunjukkan bahwa: 1) Hasil rancangan dan implementasi emodul yang telah dikembangkan pada mata pelajaran pemrograman web untuk siswa kelas X Teknik Komputer dan Jaringan dengan menggunakan model pembelajaran Project Based Learning di SMK Negeri 3 Singaraja dinyatakan berhasil diterapkan berdasarkan beberapa uji yang dilakukan. 2) Hasil analisis data respon siswa menunjukkan bahwa persentase siswa yang memberikan respon sangat baik sebesar $16 \%$, persentase siswa yang memberikan respon baik sebesar $84 \%$, dan tidak ada siswa yang memberikan respon cukup, kurang, maupun sangat kurang. Sedangkan hasil analisis data respon guru menunjukkan bahwa persentase guru yang memberikan respon sangat baik sebesar $100 \%$, dan tidak ada guru yang memberikan respon baik, cukup, kurang, maupun sangat kurang.
\end{abstract}

Kata kunci: E-Modul, Pemrograman Web, Model Project Based Learning

\section{Abstract}

The purposes of this research were (1) To design and implement of the Development of E-module based the Project Based Learning on the Web Programming Subject of the $X$ grade of SMK Negeri 3 Singaraja. (2) To know the students and the teachers response toward the Development of E-module based of Project Based Learning on the Web Programming Subject in X grade of SMK Negeri 3 Singaraja.

The method that used in this research was research and development by ADDIE development model. The subjects of the study were all of the students and the teachers of $X$ grade of Computer and Networking Engineering department of SMK Negeri 3 Singaraja in the academic year 2016/2017. To know the students and the teachers response toward the e-module obtained was collected by questionnaires method.

The results has showed that: 1) The design and implementation of e-module that was developed on the web programming for the students of $\mathrm{X}$ grade of Computer 
and Networking Engineering department of SMK Negeri 3 Singaraja by using model Project Based Learning was successfully applied according the several test that has done before, 2) The results of the data analysis of students response have indicated that the percentage of $16 \%$ were good, the precentage of good were $84 \%$, and no student response was for moderate, deficient, nor very deficient. Besides, the results of the teachers response data analysis showed that the percentage of $100 \%$ for very well response and no teacher gave for good, moderate, deficient, nor very deficient.

Keywords : E-Module, Web Programming, Project Based Learning Model

\section{PENDAHULUAN}

Sekolah Menengah Kejuruan (SMK) merupakan salah satu bentuk satuan pendidikan formal yang menyelenggarakan pendidikan kejuruan pada jenjang menengah sebagai lanjutan dari SMP, MTs atau bentuk lain yang sederajat. SMK memiliki tujuan untuk mempersiapkan peserta didik untuk bekerja sesuai dengan bidang kompetensi yang di kuasainya. Secara garis besar tujuan lain di selenggarakannya sekolah kejuruan adalah untuk mebekali lulusan dengan kompetensi yang berguna bagi karir dan kehidupan bermasyarakat.

SMK Negeri 3 Singaraja merupakan salah satu SMK di Kabupaten Buleleng yang tetap menggunakan Kurikulum 2013 karena sudah 3 semester menggunakan kurikulum ini. SMK Negeri 3 Singaraja memiliki sepuluh (10) kompetensi keahlian, salah satunya adalah Kompetensi Keahlian Teknik Komputer Jaringan. Teknik Komputer Jaringan adalah program keahlian yang mempelajari tentang komputer dan jaringan komputer, dari proses perancangan, perakitan, perawatan sampai keamanan sistem komputer dan jaringan komputer, sehingga semua mata pelajaran kejuruan yang disajikan dalam kurikulum diarahkan pada hal tersebut di atas. Di dalam kompetensi keahlian teknik komputer jaringan terdapat mata pelajaran khusus yaitu mata pelajaran produktif, dimana selama menempuh mata pelajaran produktif siswa harus mencapai kompetensi-kompetensi yang telah ditetapkan oleh sekolah. Salah satu mata pelajaran produktif yang terdapat pada kompetensi Keahlian Teknik Komputer Jaringan adalah mata pelajaran Pemrograman Web. Mata pelajaran Pemrograman Web bertujuan memberikan pemahaman dan penguasaan pengetahuan serta keterampilan tentang konsep format teks halaman web, format tabel halaman web, multimedia pada halaman web, hyperlink halaman web, formulir halaman web, style halaman web, teknik pemrograman halaman web, pengolahan input user. Berdasarkan standar isi mata pelajaran produktif SMK yang menekankan pada kemandirian siswa dan pemberian pengalaman belajar langsung, maka dalam pembelajaran pemrograman web diperlukan sebuah media yang dapat mendukung aktivitas siswa dalam mempelajari pemrograman web sehingga siswa dapat belajar mandiri tanpa harus bergantung pada guru mata pelajaran dalam mengembangkan bakat dan potensi yang dimiliki.

Berdasarkan observasi awal yang telah dilakukan di SMK Negeri 3 Singaraja dengan menggunakan angket karakteristik siswa yang dibagikan kepada seluruh siswa kelas $X$ TKJ SMK Negeri 3 Singaraja sebanyak 94 responden serta di sertai sedikit wawancara, didapatkan beberapa permasalahan diantaranya dalam proses pembelajaran setelah pemberian materi guru langsung ke praktikum tidak menjelaskan terlebih dahulu materi yang diberikan, selain itu siswa belum dapat mengerti dengan benar apa yang diajari oleh guru karena lumayan cepat dalam mengajar, dan permasalahan lain siswa sering mencari materi di internet karena kurang lengkap dan terperincinya modul atau sumber belajar yang telah diberikan. Dari permasalahan tersebut mereka memerlukan suatu wadah untuk mengakses materi pembelajaran dimana sudah terangkum keseluruhan materi yang harus mereka pelajari khususnya dalam mata pelajaran pemrograman web agar proses pembelajaran menjadi semakin 
baik dan efektif serta bisa dipelajari dimana saja dan kapan saja. Berdasarkan hasil analis angket yang diberikan kepada siswa kelas $X$ Teknik Komputer dan Jaringan sebanyak 94 responden dengan presentase sebanyak $82,98 \%$ menyatakan setuju dan 17,02\% menyatakan kurang setuju yang sebagian besar dikarenakan malas dalam membaca modul elektronik atau situs lainnya. Dari angket guru yang diberikan kepada I Kadek Dwi Sucipta selaku guru dari mata pelarajaran pemrograman web menyatakan sangat perlu dikembangkannya e-modul untuk mempermudah siswa belajar yang bersifat sistematis dan terurut dari dasar sampai tingkat lanjut.

Salah satu bahan ajar yang efektif, efisien dan mengutamakan kemandirian siswa adalah bahan ajar berupa modul. Modul merupakan suatu cara pengorganisasian materi pelajaran yang memperhatikan fungsi pendidikan (Santyasa, 2009). Artinya, melalui modul suatu pembelajaran diharapkan mampu membawa peserta didik pada kompetensi dasar yang diharapkan.

Adanya perkembangan teknologi informasi sangat berpengaruh besar pada proses belajar mengajar. Dimana tekonologi informasi sering digunakan sebagai sarana atau alat dalam menyampaikan kegiatan belajar. Salah satu penerapan teknologi informasi dalam kegiatan pembelarajan yaitu modul elektronik (e-modul). Seperti perubahan bahan ajar yang awalnya berbentuk cetak menjadi elektronik. Hal ini karena sifat modul yang dirancang khusus untuk sarana belajar mandiri. Keberadaan media pembelajaran ini pada akhirnya dapat menunjang dan melengkapi peran guru sebagai satu-satunya sumber informasi bagi peserta didik.

Dimana dalam proses pembelajaran pemrograman web kelas $X$ di SMK N 3 Singaraja menggunakan model pembelajaran berbasis proyek (Projeck Based Learning). Pembelajaran berbasis proyek adalah suatu model pembelajaran yang melibatkan suatu proyek dalam proses pembelajaran. Proyek yang dikerjakan oleh siswa dapat berupa proyek perseorangan atau kelompok dan dilaksanakan dalam jangka waktu tertentu secara kolaboratif, menghasilkan sebuah produk, yang hasilnya kemudian akan ditampilkan dan dipresentasikan. Munculnya model pembelajaran berbasis Proyek (Project Based Learning) berangkat dari pandangan konstruktivism yang mengacu pada pembelajaran kontekstual (Dimhad, 2014). Demikian pembelajaran berbasis proyek merupakan metode yang menggunakan belajar kontekstual, dimana para siswa berperan aktif untuk memecahkan masalah, mengambil keputusan, meneliti, mempresentasikan, dan membuat dokumen. Pembelajaran berbasis proyek dirancang untuk digunaklan pada masalah kompleks yang diperlukan siswa dalam melakukan investigasi dan memahaminya. Beberapa keuntungan dari pembelajaran berbasis proyek antara lain sebagai berikut: (a)Increased motivation, (b)Increased problem-solving ability, (c)Improved library research skills, (d)Increased collaboration, dan (e) Increased resource-management skills (Moursund, 1997).

Terkait dengan penelitian yang dilakukan Dita Resti Andika Sari tahun 2015 tentang Tingkat kesiapan implementasi E-Learning di SMKN 3 Singaraja dalam hal psychological readiness,sosiological readiness, environmental readiness, human resources readiness, financial readiness, technological skill (aptitude) readiness, equipment readiness, dan content readiness dengan konversi tingkat pencapaian presentase $76 \%<X \leq 100 \%$ dalam kategori sangat siap, presentase $51 \%<X \leq 76 \%$ dalam kategori siap, presentase $26 \%<X \leq 51 \%$ dalam kategori kurang siap, dan presentase $0 \% \leq X \leq$ $26 \%$ dengan kategori tidak siap. Secara umum dapat dikatakan siap, dimana kesiapan implementasi e-learning bagi guru adalah sebesar $78.02 \%$ dengan kategori sangat siap, bagi siswa adalah sebesar $71.99 \%$ dengan kategori siap, dan bagi pegawai adalah sebesar $72.27 \%$ dengan kategori siap. Rata-rata persentase dari masing-masing responden adalah $74,09 \%$. Itu artinya sebagian besar warga SMK Negeri 3 Singaraja yaitu guru, 
siswa dan pegawai berada pada kategori siap dalam mengimplementasi e-learning (Sari, 2015).

Berdasarkan uraian di atas, maka tujuan utama dari penelitian ini adalah untuk mengembangkan bahan ajar berupa e-modul berbasis Project Based Learningpada Mata Pelajaran Pemrograman Web Kelas $X$ di SMK Negeri 3 Singaraja. Yang di harapkan mampu menangani permasalahan yang di hadapi guru dan siswa dalam proses pembelajaran.

\section{Modul Ajar}

Modul adalah suatu proses pembelajaran mengenai suatu satuan bahasan tertentu yang disusun secara sistematis, operasional dan terarah untuk digunakan oleh peserta didik, disertai dengan pedoman penggunaan untuk para pengajar (Education, 2008). Modul merupakan suatu cara pengorganisasian materi pelajaran yang memperhatikan fungsi pendidikan (Santyasa, 2009). Artinya, melalui modul suatu pembelajaran diharapkan mampu membawa peserta didik pada kompetensi dasar yang diharapkan. Strategi pengorganisasian materi pembelajaran pada modul mengandung squencing yang mengacu pada pembuatan urutan penyajian materi pelajaran, dan synthe sizing yang mengacu pada upaya untuk menunjukkan kepada peserta didik keterkaitan antara fakta, konsep, prosedur dan prinsip yang terkandung dalam materi pembelajaran (Santyasa, 2009). Untuk merancang materi pem belajaran, terdapat lima kategori kapabilitas yang dapat dipelajari oleh peserta didik, yaitu (1) informasi verbal, (2) keterampilan intelektual, (3) strategi kognitif, (4) sikap, dan (5) keterampilan motorik. Strategi pengorgani sasi an materi pembelajaran terdiri dari tiga tahapan proses berpikir, yaitu (1) pembentukan konsep, (2) intepretasi konsep, dan (3) aplikasi prinsip. Strategistrategi tersebut memegang peranan sangat penting dalam mendesain pembelajaran.

\section{E-modul (Modul Elektronik)}

Modul elektronik merupakan alat atau sarana pembelajaran yang berisi materi, metode, batasan-batasan dan cara 3 mengevaluasi yang dirancang secara sistematis dan menarik untuk mencapai kompetensi yang diharapkan. Emoduladalah bagian dari electronic based e-learning yang pembelajarannya memanfaatkan teknologi informasi dan komunikasi, terutama perangkat berupa elektronik. Artinya tidak hanya internet, melainkan semua perangkat elektronik seperti film, video kaset, OHP, slide, $L C D$ projector, tape set(Dimhad, 2014) Emodul merupakan media pembelajaran yang bersifat self-instructional yang hanya memuat satu materi pembelajaran. Kemandirian siswa lebih diutamakan dalam pemanfaatan e-modul. Salah satu mata pelajaran yang membutuhkan kemandirian adalah mata pelajaran produktif (Moh Fausih, 2015).

Perkembangan media informasi saat ini mulai mengalami masa transisi dari media cetak berangsur beralih menjadi media digital. Hal ini berdampak pada dunia pendidikan, terutama dalam hal penyajian bahan ajar. Penyajian bahan ajar tidak hanya terbatas batas media cetak saja, akan tetapi sudah memanfaatkan media digital. Salah satu bentuk penyajian tersebut adalah e-book. Buku elektronik atau e-book merupakan versi elektronik sebuah buku cetak, dibaca menggunakan perangkat elektronik dan software pembuka khusus.

\section{Model Pembelajaran Project Based Learning}

Pembelajaran berbasis proyek adalah suatu pendekatan pendidikan yang efektif yang berfokus pada kreatifitas berfikir, pemecahan masalah, dan interaksi antara siswa dengan kawan sebaya mereka untuk menciptakan dan menggunakan pengetahuan baru. Khususnya ini dilakukan dalam konteks pembelajaran aktif, dialog ilmiah dengan supervisor yang akti sebagai peneliti (Laviatan, 2008).

Pembelajaran berbasis proyek adalah suatu model pembelajaran yang 
melibatkan suatu proyek dalam proses pembelajaran. Proyek yang dikerjakan oleh siswa dapat berupa proyek perseorangan atau kelompok dan dilaksanakan dalam jangka waktu tertentu secara kolaboratif, menghasilkan sebuah produk, yang hasilnya kemudian akan ditampilkan dan dipresentasikan. Pelaksanaan proyek dilakukan secara kolaboratif dan inovatif, unik, yang berfokus pada pemecahan masalah yang berhubungan dengan kehidupan siswa. Pembelajaran berbasis proyek merupakan bagian dari metoda instruksional yang berpusat pada pebelajar.

Munculnya model pembelajaran berbasis Proyek (Project Based Learning) berangkat dari pandangan konstruktivism yang mengacu pada pembelajaran kontekstual (Sari, 2015). Pembelajaran berbasis proyek merupakan pembelajaran yang inovatif yang menekankan pada kegiatan kompleks dengan tujuan pemecahan masalah dengan berdasar pada kegiatan inkuiri. Hal itu sesuai dengan tujuan pembelajaran di sekolah yaitu siswa dapat memecahkan masalah dalam kehidupan sehari-hari (Laviatan, 2008).

Langkah-langkah pelaksanaan pembelajaran berbasis proyek adalah sebagai berikut:

1) Penentuan proyek

Pada langkah ini, peserta didik menentukan tema/topik proyek berdasarkan tugas proyek yang diberikan oleh guru. Peserta didik diberikan kesempatan untuk memilih/menentukan proyek yang akan dikerjakannya baik secara kelompok ataupun mandiri dengan catatan tidak menyimpang dari tugas yang diberikan guru.

2) Perancangan langkah-langkah penyusunan jadwal pelaksanaan proyek

Peserta didik merancang langkahlangkah kegiatan penyelesaian proyek dari awal sampai akhir beserta pengelolaannya. Kegiatan perancangan proyek ini berisi aturan main dalam pelaksanaan tugas proyek, pemilihan aktivitas yang dapat mendukung tugas proyek, pengintegrasian berbagai kemungkinan penyelesaian tugas proyek, perencanaan sumber/bahan/alat yang dapat mendukung penyelesaian tugas proyek, dan kerja sama antara anggota kelompok.

3) Penyusunan jadwal pelaksanaan proyek

Peserta didik dibawah pendampingan guru melakukan penjadwalan semua kegiatan yang telah dirancangnya. Berapa lama proyek itu harus diselesaikan tahap demi tahap.

4) Penyelesaian proyek dengan fasilitasi dan monitoring guru

Langkah ini merupakan langkah pengimplementasian rancangan proyek yang telah dibuat. Aktivitas yang dapat dilakukan dalam kegiatan proyek diantaranya adalah dengan a) membaca, b) meneliti, c) observasi, d) interview, e) merekam, f) berkarya seni, g) mengunjungi objek proyek, atau h) akses internet. Guru bertanggung jawab memonitor aktivitas peserta didik dalam melakukan tugas proyek mulai proses hingga penyelesaian proyek. Pada kegiatan monitoring, guru membuat rubric yang akan dapat merekam aktivitas peserta didik dalam menyelesaikan tugas proyek

5) Penyusunan laporan dan presentasi/publikasi hasil proyek Hasil proyek dalam bentuk produk, baik itu berupa produk karya tulis karya seni, atau karya teknologi/prakarya dipresentasikan dan/atau dipublikasikan kepada peserta didik yang lain dan guru atau masyarakat dalam bentuk pameran produk pembelajaran.

6) Evaluasi proses dan hasil proyek

Guru dan peserta didik pada akhir proses pembelajaran melakukan refleksi terhadap aktivitas dan hasil tugas proyek. Proses refleksi pada tugas proyek dapat dilakukan secara individu maupun kelompok. Pada tahap evaluasi, peserta didik diberi kesempatan mengemukakan pengalamannya selama menyelesaikan tugas proyek yang berkembang dengan 
diskusi untuk memperbaiki kinerja selama menyelesaikan tugas proyek. Pada tahap ini juga dilakukan umpan balik terhadap proses dan produk yang telah dihasilkan.

\section{Mata Pelajaran Pemrograman Web}

Pemrograan Web adalah salah satu mata pelajaran wajib paket keahlian Teknik Komputer Dan Jaringan yang harus dicapai oleh siswa SMK. Mata pelajaran Pemrograman Web bertujuan memberikan pemahaman dan penguasaan pengetahuan serta keterampilan tentang konsep format teks halaman web, format tabel halaman web, multimedia pada halaman web, hyperlink halaman web, formulir halaman web, style halaman web, teknik pemrograman halaman web, pengolahan input user.

Berdasarkan struktur kurikulum, mata pelajaran Pemrograman Web disampaikan di kelas $X$ semester 1 (satu) dan semester 2 (dua) masing-masing 4 jam pelajaran. Untuk semester 1 topik materi pembelajaran menekankan pada format teks halaman web, format tabel halaman web, multimedia pada halaman web, hyperlink halaman web, formulir halaman web. Sedangkan untuk semester 2 topik materi pembelajaran menekankan pada style halaman web, teknik pemrograman halaman web, pengolahan input user. Dalam tabel 1 dijelaskan tentang Kompetensi Inti, Kompetensi Dasar, dan Materi Pokok yang akan digunakan dalam e-modulPemrograman Web.

\section{MOODLE}

Moodle merupakan salah satu paket software untuk membuat suatu pelatihanpelatihan berbasis web dan internet yang biasa disebut sebagai Learning Management System (LMS) / Course Management System (CMS) / Virtual Learning Management (VLE). Moodle disediakan secara gratis dan bebas digunakan karena merupakan software open sourch (dibawah lisensi GNU Public). Kata moodle awalnya merupakan kependekan dari Modulator ObjectOriented Dynamic Learning Environment, walaupun pada awalnya huruf $M$ kependekan dari kata "Martin's" yang berasal dari Martin Dougiamas sang pembuat moodle. Maksud dari modular disini adalah para developer di seluruh dunia dapat mengembangkan serta menciptakan module-module baru untuk menambah fungsional moodle. Moodle dapat diinstal pada Windows, Mac, dan berbagai distro Linux yang dapat menjalankan PHP dan mendukung database bertipe SQL (MySQL, Postgre, Oracle, ataupun Microsoft Oracle SQL Server). Moodle merupakan produk yang sangat aktif dan cepat perkembangannya. Seiring perkembangannya, banyak fungsifungsi baru yang ditambahkan.

\section{Kerangka Berpikir}

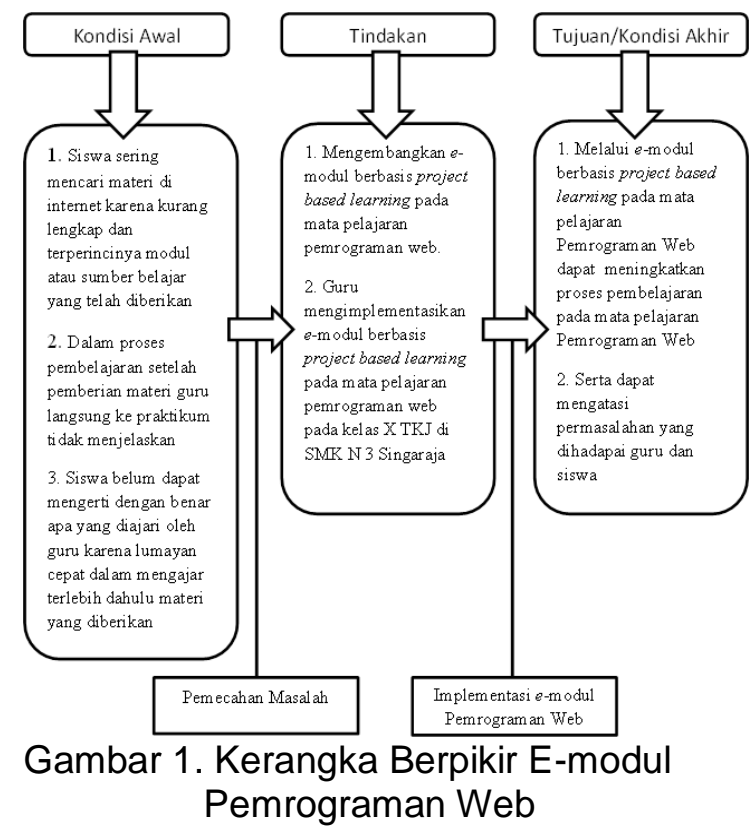

Berdasarkan observasi di SMK N 3 Singaraja kelas $X$ TKJ pada mata pelajaran Pemrograman Web siswa sering mencari materi di internet karena kurang lengkap dan terperincinya modul atau sumber belajar yang telah diberikan, dalam proses pembelajaran setelah pemberian materi guru langsung ke praktikum tidak menjelaskan terlebih dahulu materi yang diberikan, dan siswa belum dapat mengerti dengan benar apa yang diajari oleh guru karena lumayan cepat dalam mengajar.

Dengan permasalahan seperti itu maka peneliti pengembangkan e-modul berbasis project based learning pada mata 
pelajaran Pemrograman Web guna membantu guru dan siswa dalam mengatasi permasalahan dalam proses pembelajaran. selain itu juga proses pembelajaran menjadi berfokus pada siswa. Berikut merupakan gambar dari kerangka berpikir.

\section{METODE}

Metode penelitian yang digunakan pada penelitian ini adalah metode penelitian dan pengembangan. Selain itu, Sukmadinata (2010) juga menyatakan penelitian dan pengembangan adalah suatu proses atau langkah-langkah untuk mengembangkan produk yang telah ada, yang dapat dipertanggung jawabkan.produk tersebut tidak selalu berbentuk benda atau perangkat keras (hardware), seperti buku, modul, alat bantu pembelajaran dikelas atau laboratorium, tetapi bisa juga perangkat lunak (software), seperti program computer pengolah data, pembelajaran dikelas, perpustakaan atau laboratorium, ataupun model-model pendidikan, pembelajaran, pelatihan, bimbingan, evaluasi, manajemen, dan lain lain.

Model pengembangan yang digunakan untuk mengembangkan $e$ modul berbasis project based learning pada mata pelajaran pemrograman web adalah model pengembangan ADDIE. Pemilihan model ini didasari atas pertimbangan bahwa model ini dikembangkan secara sistematis dan berpijak pada landasan teoretis desain pembelajaran. Model ini disusun secara terprogram dengan urutan-urutan kegiatan yang sistematis dalam upaya pemecahan masalah belajar yang berkaitan dengan sumber belajar yang sesuai dengan kebutuhan dan karakteristik pebelajar.Model ini terdiri atas lima langkah, yaitu: (1) analisis (analyze), (2) perancangan (design), (3) pengembangan (development), (4) implementasi (implementation), dan (5) evaluasi (evaluation). Secara visual tahapan ADDIE Model dapat dilihat pada Gambar 2.

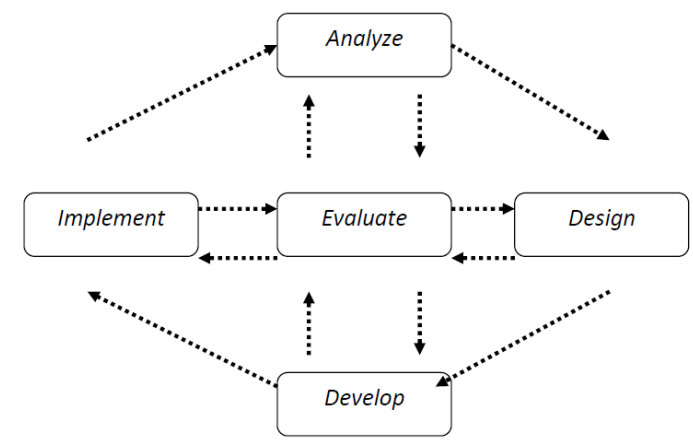

Gambar 2. Tahapan Model ADDIE

Pada tahap pengumpulan data ini data yang dikumpulkan berupa informasi mengenai sumber belajar, karakteristik siswa serta respon guru dan siswa terhadap pengembangan e-modul. Berikut merupakan teknik pengumpulan data dalam bentuk tabel.

Tabel 1. Teknik Pengumpulan Data

\begin{tabular}{clcll}
\hline No & \multicolumn{1}{c}{ Jenis Data } & Metode & $\begin{array}{l}\text { Alat Pengumpulan } \\
\text { Data }\end{array}$ & Sumber Data \\
\hline 1 & $\begin{array}{l}\text { Informasi tentang } \\
\text { sumber belajar }\end{array}$ & Wawancara & Observasi & $\begin{array}{l}\text { Guru Mata } \\
\text { Pelajaran Simulasi } \\
\text { Digital di SMK } \\
\text { Negeri 2 Singaraja } \\
\text { Siswa kelas X Tata } \\
\text { Boga 5 }\end{array}$ \\
2 & $\begin{array}{l}\text { Informasi proses } \\
\text { pembelajaran } \\
\text { simulasi digital } \\
\text { Kevalidan e- } \\
\text { modul }\end{array}$ & Kuisioner & Angket & $\begin{array}{l}\text { Ahli isi, ahli desain } \\
\text { pembelajaran dan } \\
\text { ahli media }\end{array}$ \\
& Kuisioner & Angket & Siswa kelas X Tata \\
Boga 5
\end{tabular}


Metode wawancara digunakan untuk menggali informasi tentang materi yang diajarkan pada mata pelajaran Pemrograman Web yang tertuang dalam bentuk silabus dalam Tabel 1 dan untuk mendapatkan informasi tentang sumber belajar yang ada di sekolah. Angket Karakteristik Pelajar digunakan untuk mencari informasi tentang ketertarikan siswa terhadap pelajaran Pemrograman Web. Sedangkan angket kevalidan modul dan respon siswa digunakan untuk tahap validasi yang dilakukan oleh para ahli serta untuk mengetahui respon siswa terhadap e-modul yang dikembangkan.

Berikut merupakan penjelasan tentang teknik analisis data yang digunakan dalam penelitian ini.

a) Analisis data kevalidan E-modul

Analisis data kevalidan e-modul adalah untuk mengetahui perkembangan $e$ modul yang telah dibuat apakah sudah memenuhi kriteria berdasarkan penilaian validator yang ditunjuk dengan menggunakan lembar validasi ahli, hasil dari validasi ahli yang menjadi dasar dan pertimbangan dalam melakukan revisi dimana yang ditunjuk sebagai ahli adalah Dosen yang berspesifikasi Magister (S2) di Jurusan Pendidikan Teknik informatika Undiksha.

b) Analisis data respon siswa dan Guru Analisis respon siswa dan guru bertujuan unuk mengetahui bagaiamana respon dari siswa terhadap pengembangan e-modul. Hasil penilaian untuk uji perorangan dan uji kelompok kecil dihitung dengan menggunakan persamaan 1 dan persamaan 2 .

Persentase $=\frac{\sum \text { Jawraban } \times \text { Bobot Tiap soaD }}{n \times \text { Eobot Tertinggi }} \times 100 \% \ldots \ldots \ldots$

Untuk presentase keseluruhan subyek dapat dihitung dengan menggunakan persamaan 2.

Persentase $=\frac{\text { Jumiah Presentase Reseluruhan Subyek }}{\text { Banyak Swbyek }} \ldots \ldots$

Hasil penilaian dari uji perorangan, uji kelompok kecil dan respon siswa dikonversikan dengan menggunakan pedoman seperti yang disajikan pada Tabel 2.

Tabel 2. Konversi Tingkat Pencapaian

\begin{tabular}{lll}
\hline Tingkat Pencapaian & Kualifikasi & Keterangan \\
\hline $90 \%-100 \%$ & Sangat Baik & Tidak perlu direvisi \\
$75 \%-89 \%$ & Baik & Sedikit Direvisi \\
$65 \%-74 \%$ & Cukup & Direvisi Secukupnya \\
$55 \%-64 \%$ & Kurang & Banyak Hal yang Direvisi \\
$0-54 \%$ & Sangat Kurang & Diulang Membuat Produk \\
\hline
\end{tabular}

\section{HASIL DAN PEMBAHASAN}

Pengembangan e-modul mata pelajaran Pemrograman Web dimaksudkan sebagai pemahaman dasar siswa dalam pengembangan web yang nantinya menjadi dasar untuk mata pelajaran pemrograman web selanjutnya. Dari hasil analisis sumber belajar yang dilakukan, siswa belum menggunakan emodul dalam proses pembelajaran. Dengandemikian pengembangan e-modul pemrograman web sangat diperlukan khususnya pada Program Keahlian Teknik komputer dan Jaringan kelas $\mathrm{X}$ di SMK Negeri 3 Singaraja.
Pengembangan e-modul pemrograman web bertujuan untuk membantu siswa dalam memahami mata pelajaran pemrograman. Dalam pengembangan e-modul pemrograman web menggunakan model pembelajaran Project Based Learning agar siswa menghasilkan suatu proyek di akhir pembelajaran serta pembelajaran dapat berpusat pada siswa.

Sesuai dengan paparan hasil penelitian, berikut ini diuraikan pembahasan yang dilakukan peneliti. Pembahasan difokuskan pada penyajian dan analisis data serta revisi yang dilakukan terhadap produk 
pengembangan. Tahap pertama menentukan mata pelajaran yang menjadi objek penelitian yaitu mata pelajaran Pemrograman Web. Tahap kedua yaitu menganalisis kebutuhan dari mata pelajaran pemrograman web. Tahap ketiga adalah proses pengembangan draft, yaitu (a) analisis kondisi pembelajaran, (b) langkah pengembangan, dan (c) Langkah Pengukuran Hasil Belajar dimana tahap ini tidak dilakukan oleh peneliti. Tahap Keempat pengembangan media menggunakan model ADDIE, yang meliputi (1) analisis (analyze), (2) perancangan (design), (3) pengembangan (development), (4) implementasi (implementation), dan (5) evaluasi (evaluation). Tahap Kelima adalah tahap terakhir dalam pengembangan e-modul pemrograman web yaitu tinjauan ahli dan uji coba e- modul.

Tahap pertama dalam pengembangan e-modul ini adalah menentukan mata pelajaran yang menjadi objek pengembangan, dalam penelitian ini adalah mata pelajaran PemrogramanWeb.

Tahap kedua dalam pengembangan bahan ajar pemrograman web berbasis Project Based Learning ini adalah analisis kebutuhan. Analisis kebutuhan merupakan kegiatan menganalisis materi dalam matapelajaran dari silabus untuk memperoleh informasi modul yang dibutuhkan siswa dalam mempelajari kompetensi yang telah diprogramkan. Pada tahap ini menentukan kebutuhankebutuhan yang dilakukan terkait permasalahan yang ditentukan pada tahap pertama. Analisis kebutuhan yang dilakukan adalah menganalisis media pembelajaran yang sesuai dengan pebelajar. Media yang digunakan adalah media berupa e-modul berbasis Moodle. Hal ini dikarenakan e-modul berbasis Moodle yang akan dikembangkan mampu memantau perkembangan pemahaman siswa terhadap materi pembelajaran.

Tahap ketiga adalah tahap pengembangan media menggunakan model ADDIE. Pada tahap ini adalah tahap perancangan hingga pembuatan media berupa e-modul, tahap ini meliputi analisis kondisi pembelajaran, analisis use case diagram dan activity diagram, perancangan (design), meliputi penyusunan rancangan antarmuka tampilan e-modul, pengembangan rancangan antarmuka, membuat hak akses masuk ke halaman mata pelajaran, menyusun tampilan masing-masing pengguna (admin, guru dan siswa), mengatur tampilan kegiatan pembelajaran, serta menerapkan modul ke sistem emodul.

Tampilan halaman utama dari emodul setelah melakukan login disajikan pada Gambar 3.

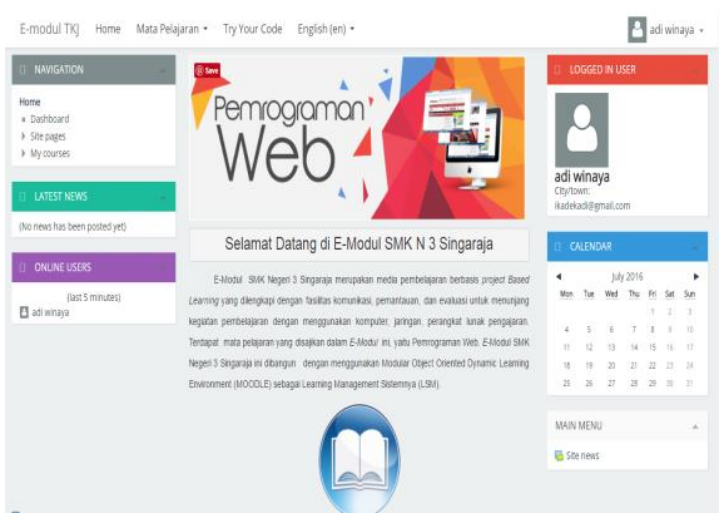

Gambar 3. Tampilan Halaman Utama

Hasil pengembangan halaman login dapat dilihat pada Gambar 4.

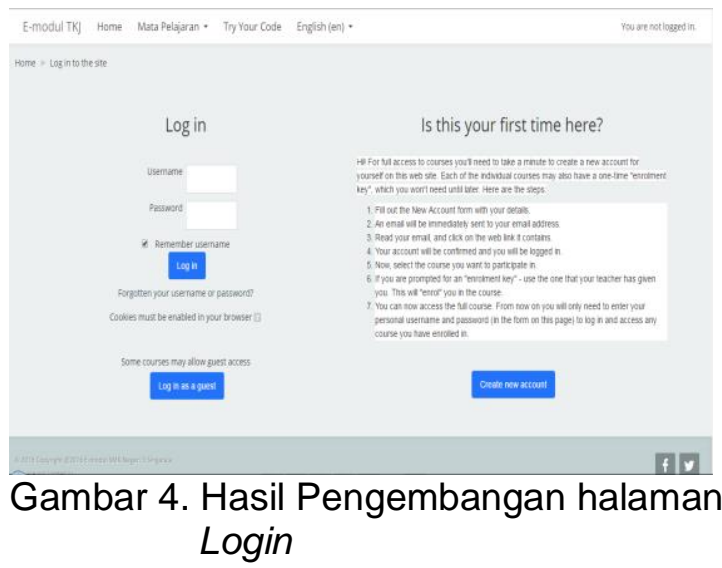

Hasil pengembangan halaman kegiatan belajar dapat dilihat pada Gambar 


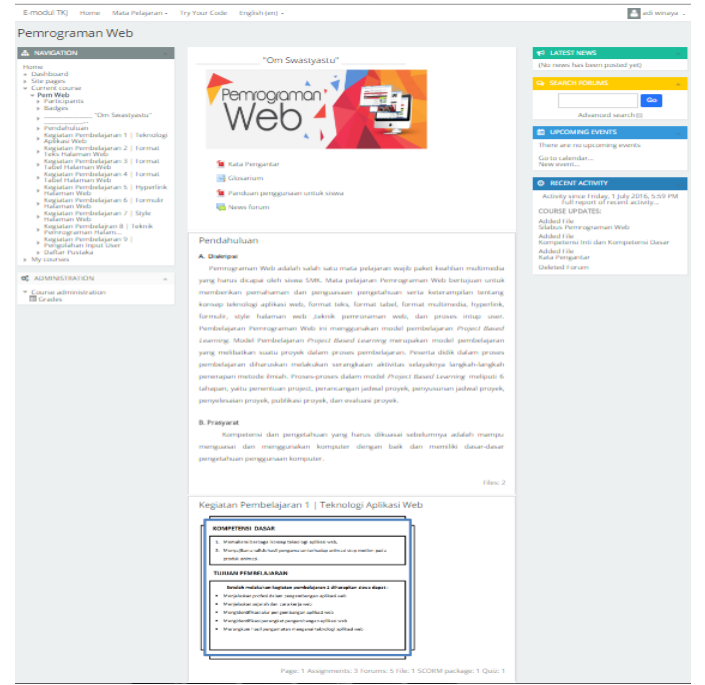

Gambar 5. Hasil Pengembangan

Halaman Kegiatan

Pembelajaran

Selanjutnya implementasi yang meliputi evaluasi ahli desain pembelajaran, evalauasi ahli media, uji perorangan, uji kelompok kecil, uji respon guru dan uji coba lapangan.

Hasil penilaian ahli isi berdasarkan angket sudah dinyatakan sesuai, hal tersebut mengindikasi materi yang ada di dalam e-modul layak untuk digunakan dalam pembelajaran Pemrograman Web. Beberapa masukan dari ahli isi seperti menambahkan alokasi waktu dalam $e$ modul yang disesuaikan dengan silabus telah dilakukan perubahan agar modul valid dari segi isi pembelajaran.

Hasil penilaian ahli desain pembelajaran terhadap e-modul pemrograman web berdasarkan angket sudah dinyatakan sesuai, hal tersebut mengindikasi materi yang ada di dalam e- modul dan tahapannya layak untuk digunakan dalam pembelajaran Pemrograman Web. Dari evaluasi ahli desain seperti menambahkan feedback pada setiap tes formatif, menambahkan gloarium pada setiap kegiatan pembelajaran, dan perubahan kisi-kisi dan angket telah dilakukan perubahan agar modul valid dari segi desain pembelajaran. Hasil ahli media pembelajaran terhadap e-modul pemrograman web sudah dinyatakan sesuai. Dari evaluasi ahli media, ada beberapa saran yang diberikan seperti bahasa yang digunakan mesti ringan dan disesuaikan dengan perkembangan peserta didik, tahapan pada e-modul PJBL baiknya ditulis eksplisit, peneliti konsultasikan lagi dengan ahli media dengan perubahan yang telah dibuat dan diterima sehingga $e$ modul telah valid dari segi media.

Subjek uji perorangan adalah tiga orang siswa kelas X TKJ1. Dari hasil angket uji coba yang diisi oleh masingmasing siswa, semua siswa memberikan tanggapan baik, dan tidak ada siswa yang memberikan tanggapan cukup, kurang maupun sangat kurang. Jika dikonversikan ke dalam tabel konversi termasuk dalam kategori baik dan layak untuk dilanjutkan.

Setelah dikonversi dengan tabel konversi, presentase tingkat pencapaian isi e-modul yaitu $83,16 \%$ berada pada kualifikasi baik. Namun dilihat dari hasil pencapaian, masih terdapat $16,84 \%$ untuk dilakukan revisi, jadi peneliti melakukan revisi lewat saran dari responden. Konversi pencapaian dapat dilihat pada Tabel 3.

Tabel 3. Konversi Pencapaian

\begin{tabular}{lcc}
\hline $\begin{array}{l}\text { Konversi Tingkat } \\
\text { Pencapaian }\end{array}$ & $\begin{array}{c}\text { Persentase } \\
(\%)\end{array}$ & $\begin{array}{c}\text { Jumlah Responden } \\
\text { (orang) }\end{array}$ \\
\hline Sangat Baik & $0 \%$ & 0 \\
Baik & $100 \%$ & 3 \\
Cukup & $0 \%$ & 0 \\
Kurang & $0 \%$ & 0 \\
Sangat Kurang & $0 \%$ & 0
\end{tabular}


Berdasarkan Rekapitulasi penilaian dari masing-masing responden yang terlihat pada Tabel 3 memperlihatkan penilaian yang diberikan oleh siswa adalah sangat baik $0 \%$, baik $100 \%$, cukup $0 \%$, kurang $0 \%$, dan sangat kurang $0 \%$. Hal ini mengindikasi bahwa pengembangan e-modul mata pelajaran pemrograman web menunjukan keberhasilan yang dibuktikan dengan terbantunya siswa dalam hal pemerolehan sumber belajar.

Setelah uji perorangan selesai dan direvisi, maka dilanjutkan dengan uji kelompok kecil. Uji kelompok kecil dilakukan oleh 12 (duabelas) orang siswa kelas XTKJ1. Dari hasil angket ujicoba kelompok kecil yang diisi oleh masingmasing siswa didapatkan kategori sangat baik dan satu siswa dengan kategori baik dan layak untuk dilanjutkan.

Setelah dikonversi dengan tabel konversi, presentase tingkat pencapaian e- modul yaitu $90 \%$ berada pada kualifiasi sangat baik. Namun dilihat dari hasil pencapaian, masih terdapat 10\% untuk dilakukan revisi, jadi peniliti melakukan revisi lewat saran dari responden. Rata-rata responden memberikan skor 5 dan 4 dari 6 responden. Konversi pencapaian dapat dilihat pada Tabel 4.

\begin{tabular}{lcc}
\multicolumn{3}{c}{ Tabel 4. Konversi Penilaian pada Uji Coba Kelompok Kecil } \\
\hline $\begin{array}{l}\text { Konversi Tingkat } \\
\text { Pencapaian }\end{array}$ & $\begin{array}{c}\text { Persentase } \\
(\%)\end{array}$ & $\begin{array}{c}\text { Jumlah Responden } \\
\text { (orang) }\end{array}$ \\
\hline Sangat Baik & $58,3 \%$ & 7 \\
Baik & $41,7 \%$ & 5 \\
Cukup & $0 \%$ & 0 \\
Kurang & $0 \%$ & 0 \\
Sangat Kurang & $0 \%$ & 0 \\
\hline
\end{tabular}

Berdasarkan rekapitulasi penilaian dari masing-masing responden yang terlihat pada Tabel 4 memperlihatkan penilaian yang diberikan oleh siswa adalah sangat baik $58,3 \%$, baik $10 \%$, cukup $0 \%$, kurang $0 \%$, dan sangat kurang $0 \%$. Hal ini mengindikasi bahwa pengembangan e-modul mata pelajaran pemrograman web menunjukan keberhasilan yang dibuktikan dengan terbantunya siswa dalam hal pemrolehan sumber belajar.

Setelah ujicoba kelompok kecil selesai dilanjutkan dengan uji respon guru.
Hasil respon guru terhadap e-modul mata pelajaran pemrograman web menunjukkan tanggapan sangat baik terhadap penggunaan e-modul dengan tanggapan dua orang sangat baik dan layak untuk dilanjutkan.

Setelah dikonversi dengan tabel konversi, presentase tingkat pencapaian e-modul yaitu $100 \%$ berada pada kualifikasi sangat baik. Rata-rata responden memberikan skor 5 dan 4, tidak ada responden yang memberikan skor 3, 2, dan 1. Konversi pencapaian dapat dilihat pada Tabel 5.

Tabel 5. Konversi Penilaian pada Respon Guru

\begin{tabular}{lcc}
\hline $\begin{array}{l}\text { Konversi Tingkat } \\
\text { Pencapaian }\end{array}$ & $\begin{array}{c}\text { Persentase } \\
(\%)\end{array}$ & $\begin{array}{c}\text { Jumlah Responden } \\
\text { (orang) }\end{array}$ \\
\hline SangatBaik & $100 \%$ & 2 \\
Baik & $0 \%$ & 0
\end{tabular}




$\begin{array}{lll}\text { Cukup } & 0 \% & 0 \\ \text { Kurang } & 0 \% & 0 \\ \text { SangatKurang } & 0 \% & 0\end{array}$

Berdasarkan rekapitulasi penilaian dari masing-masing responden memperlihatkan penilaian yang diberikan oleh guru adalah sangat baik $100 \%$, baik $0 \%$, cukup $0 \%$, kurang $0 \%$, dan sangat kurang $0 \%$. Penilaian ini sejalan dengan rerata skor seluruh responden yang diperoleh pada analisis yang dilakukan pada Tabel 5. Hal ini mengindikasi bahwa pengembangan e-modul mata pelajaran pemrograman web menunjukan keberhasilan yang dibuktikan dengan terbantunya siswa dalam hal pemrolehan sumber belajar.

Kemudian dilanjutkan dengan uji respon siswa. Subjek uji respon siswa adalah siswa kelas $X$ TKJ Program
Keahlian Teknik Komputer dan Jaringan yang berjumlah 25 orang. Hasil angket terhadap seluruh siswa kelas $\mathrm{X}$ TKJ1 menunjukkan bahwa e-modul pemrograman web mendapatkan respon baik dan hanya 5 siswa memberikan respon sangat baik .

Setelah dikonversi dengan tabel konversi, presentase tingkat pencapaian e-modul yaitu sangat baik $16 \%$, baik $84 \%$, cukup $0 \%$, kurang $0 \%$, dan sangat kurang $0 \%$. Rata-rata responden memberikan skor 5, 4, 3, dan 2 tidak ada responden yang memberikan skor 1 . Konversi tingkat pencapaian pada uji respon siswa disajikan pada Tabel 6 .

Tabel 6. Konversi Pencapaian pada Uji Respon Siswa

\begin{tabular}{lcc}
$\begin{array}{l}\text { Konversi Tingkat } \\
\text { pencapaian }\end{array}$ & $\begin{array}{c}\text { Persentase } \\
(\%)\end{array}$ & $\begin{array}{c}\text { Jumlah Responden } \\
\text { (orang) }\end{array}$ \\
\hline Sangat Baik & $16 \%$ & 4 \\
Baik & $84 \%$ & 21 \\
Cukup & $0 \%$ & 0 \\
Kurang & $0 \%$ & 0 \\
Sangat Kurang & $0 \%$ & 0 \\
\hline
\end{tabular}

Berdasarkan rekapitulasi penilaian dari masing-masing responden yang terlihat pada Tabel 6 memperlihatkan penilaian yang diberikan oleh siswa adalah sangat baik $16 \%$, baik $84 \%$, cukup $0 \%$, kurang $0 \%$, dan sangat kurang $0 \%$. Penilaian ini sejalan dengan rerata skor seluruh responden yang diperoleh pada analisis yang dilakukan penulis. Hal ini mengindikasi bahwa pengembangan $e$ modul mata pelajaran pemrograman web menunjukan keberhasilan yang dibuktikan dengan terbantunya siswa dalam hal pemrolehan sumber belajar.

Berdasarkan pembahasan di atas, dapat disimpulkan bahwa hasil penelitian menunjukkan penilaian kelayakan e-modul pemrograman web berdasarkan ahli isi termasuk kategori sangat layak, ahli desain pembelajaran termasuk kategori layak, ahli media termasuk kategori layak, dan uji coba lapangan terhadap guru dan siswa termasuk dalam kategori sangat baik. Maka dari penilaian tersebut dapat disimpulkan bahwa e-modul pemrograman web berbasis Project Based Learning layak digunakan untuk sumber belajar untuk SMK Negeri 3 Singaraja kompetensi keahlian Teknik Komputer dan Jaringan kelas $X$, dan diharapkan mampu membantu kinerja guru dalam proses pembelajaran dan siswa diharapkan dapat 
belajar secara mandiri di sekolah maupun dirumah.

\section{SIMPULAN DAN SARAN}

Berdasarkan hasil analisis data dan pembahasan pada penelitian ini, maka dapat diambil simpulan sebagai berikut.

Hasil rancangan dan implementasi e-modul yang telah dikembangkan pada mata pelajaran pemrograman web untuk siswa kelas $X$ Teknik Komputer dan jaringan dengan menggunakan model pembelajaran Project Based Learning di SMK Negeri 3 Singaraja dinyatakan berhasil diterapkan berdasarkan 1) uji ahli isi mata pelajaran, 2) uji desain pembelajaran, dan 3) uji media pembelajaran yang telah dilakukan. Desain yang dilakukan sebelumnya sesuai dengan e-modul yang dikembangkan, diantaranya tentang rancangan fitur yang digunakan seperti Page, Forum, Assignments, File, dan Quizzes.

Berdasarkan respon siswa pada emodul mata pelajaran pemrograman web berbasis Project Based Learning untuk kelas $X$ Kompetensi Keahlian Teknik Komputer dan Jaringan di SMK Negeri 3 Singaraja, didapatkan rata-rata respon siswa sebesar 82,6\% dalam hal kesesuaian tampilan, kemudahan penggunaan e-modul, motivasi terhadap siswa dan isi konten. Jika dikonversikan ke dalam tabel konversi tingkat pencapaian termasuk pada kategori baik. Sedangkan untuk respon guru terhadap $e$ modul didapatkan rata-rata respon sebesar $94 \%$ dalam hal kemudahan penggunaan e-modul, antusias siswa, dan pengajaran menggunakan e-modul. Jika dikonversikan ke dalam tabel konversi tingkat pencapaian termasuk pada kategori sangat baik.

Berdasarkan pengamatan penulis di lapangan, terdapat beberapa hal yang dapat dijadikan bahan pertimbangan untuk ditindak lanjuti, yaitu:

Produk e-modul pemrograman web berbasis Project Based Learning di SMK Negeri 3 Singaraja yang dikembangkan belum sampai pada tahap pengukuran hasil belajar akhir siswa dengan e-modul. Oleh karena itu, terbuka bagi para peneliti lain untuk mengkaji lebih jauh pengukuran hasil belajar akhir siswa menggunakan emodul ini.

\section{DAFTAR PUSTAKA}

Santyasa, I. W. (2009). Metode Penelitian Pengembangan dan Teori Pengembangan Modul. Makalah disajikan dalam pelatihan bagi guru TK, SMP, SMA dan SMK tanggal 1214 Januari 2014, di Kecamatan Nusa Penida Kabupaten Klungkung. Singaraja: Undiksha.

Khamdi, W. (2008). Project-Based Learning: Pendekatan Pembelajaran Inovatif. Malang: Universitas Negeri Malang.

Dimhad. (2014). Penggunaan E-Modul Interaktif Melalui Pembelajaran Berbasis Masalah Untuk Meningkatkan Pemahaman Konsep Sistem Saraf, Kemampuan Generik Sains Dan Berpikir Kritis. Retrieved Januari 20, 2016, from http://dimhad13.110mb.com/buku6/a .pdf

Moursund,D.1997. Project: Road a Head ( ProjectBased Learning) HYPERLINK"http://www.iste.org/res eacrh/roadahead/pbl.html" It "_blank"http://www.iste.org/reseacrh/ roadahead/pbl.html. diakses pada 23 November2013

Sari, D. R. (2015). Tingkat Kesiapan Elearning (E-learning Readiness). Kumpulan Artikel Mahasiswa Pendidikan Teknik Informatika, 7.

Education, I. (2008). Modular Instruction. Retrieved Januari 20, 2016, from http://primasoft.wordpress.com/ 20 $08 / 03 / 31 / \mathrm{modular}$-instru c t i o n - p emb e I a j a r a n menggunakan-modul/

Moh Fausih, D. T. (2015). Pengembangan Media E-Modul Mata Pelajaran Produktif Pokok Bahasan "Instalasi Jaringan Lan (Local Area Network)" Untuk Siswa Kelas XI Jurusan Teknik Komputer Jaringan Di Smk 
Nengeri 1 Labang Bangkalan Madura. 1.

Laviatan, $\mathrm{T}$.

(2008). InnovativeTeachingand Assessment Method: QBland Project Based Learning. MathematicsEducati, 105116.

BIBLIOGRAPHY || 1033 Fathurohman, M. (2015). Model-Model Pembelajaran Inovatif. Jogjakarta: Ar-Ruzz Media.

Anglada, D. (2007). An Introduction to Instructional Design: Utilizing a Basic Design Model. Retrieved 1 25, 2016, fromhttp://www.pace.edu/ctlt/newslet ter 